Volume 13

$12-20-2019$

\title{
Scenarios of Intractability: Reframing Intractable Conflict and Its Transformation
}

Kerry Whigham

Binghamton University

Follow this and additional works at: https://digitalcommons.usf.edu/gsp

\section{Recommended Citation}

Whigham, Kerry (2019) "Scenarios of Intractability: Reframing Intractable Conflict and Its Transformation," Genocide Studies and Prevention: An International Journal: Vol. 13: Iss. 3: 44-63.

DOI:

https://doi.org/10.5038/1911-9933.13.3.1671

Available at: https://digitalcommons.usf.edu/gsp/vol13/iss3/6

This Articles is brought to you for free and open access by the Open Access Journals at Digital Commons @ University of South Florida. It has been accepted for inclusion in Genocide Studies and Prevention: An International Journal by an authorized editor of Digital Commons @ University of South Florida. For more information, please contact digitalcommons@usf.edu. 


\title{
Scenarios of Intractability: Reframing Intractable Conflict and Its Transformation
}

\author{
Kerry Whigham \\ Binghamton University \\ Binghamton, New York, USA
}

\section{Reframing Intractable Conflict}

In the fields of atrocity and conflict prevention, certain cases continually serve as counterpoints for those advocating for the potential of bringing an end to cycles of violence. They are the cases where the divides among relevant groups seem particularly engrained, where the possibility for true peace (and not only the absence of violence) seems specifically unlikely. Some refer to these cases as deeply divided societies, ${ }^{1}$ but more often, particularly in the conflict prevention literature, they are referred to as intractable conflicts. In these cases, societies are divided into specific identity groups, which serve as predominant organizing features in their lives and their senses of belonging. Each group tends to have its own distinct understanding of the past, which serves as a foundation for continued division. These understandings of the past are also used to legitimate continued acts of physical, institutional, economic, and social violence.

Although each has its own particularities, there are similarities present across the cases. I argue, however, that by referring to these cases as "intractable conflicts," their intractability becomes somehow naturalized, appearing as an essential and immutable quality of these conflicts. In other words, the very way that the field describes and understands these specific instances of conflict is already foreclosing options for engagement and prevention, just as it is serving to obscure interventions that may have already emerged from within these conflicts that can transform the way they play out. Moreover, the language of intractability is frequently used to justify outside intervention, often in the form of trained and supposedly disinterested parties from the conflict resolution/mediation field, reinforcing a notion that the answers to transforming conflict come from without, not from within a society.

To change the way one conceives of such conflict, I advocate turning to the analytical tools of performance studies, a field based on the idea that our lives are often guided by certain scripts-predetermined behaviors that play out at all levels of society, from daily interactions with individuals to the policies initiated within the halls of government. Within these scripts, we all play certain roles. ${ }^{2}$ Certain actions are acceptable for each role, while others seem "out of character." Furthermore, history and our interpretations of it have a significant impact on these scripts. What has occurred in the past shapes what seems possible and desirable in the present and future. The past, in other words, also performs. That is, it does things. ${ }^{3}$ Nowhere is this multi-level performance more evident than in post-atrocity societies, where the past is one characterized by large-scale, systematic violence against certain identity groups. And within this pool of societies that are, in some way, post-atrocity or post-conflict, there exists a smaller subset of societies in which conflict based on identity seems especially dogged and prolonged, and the hope for social cohesion and an end to identity-based discord seems particularly unlikely.

This article applies a performance studies lens to illuminate the various ways that scenarios and historical narratives inform understandings of the present and influence visions of the future in post-atrocity societies. In particular, I focus on cases of so-called intractable conflicts. Daniel Bar-Tal writes that intractable conflicts "are characterized as being protracted, irreconcilable, violent, of a zero-sum nature, total, and central, with the parties involved having an interest in

${ }^{1}$ Arend Lijphart, "Typologies of Democratic Systems," Comparative Political Studies 1 (April 1968), 3-44; Eric Nordlinger, Conflict Regulation in Divided Societies (Cambridge, MA: Center for International Affairs, Harvard University, 1972); Adrian Guelke, Politics in Deeply Divided Societies (Cambridge, UK: Polity, 2012).

${ }^{2}$ Erving Goffman, The Presentation of Self in Everyday Life (Norwell, MA: Anchor Press, 1959); Erving Goffman, Frame Analysis: An Essay on the Organization of Experience (Boston: Northeastern University Press, 1986).

${ }^{3}$ John L. Austin, How to Do Things with Words (Cambridge, MA: Harvard University Press, 1962); Judith Butler, Excitable Speech: A Politics of the Performative (New York: Routledge, 1997); Judith Butler, "Performative Acts and Gender Constitution: An Essay in Phenomenology and Feminist Theory," in The Performance Studies Reader, ed. Henry Bial, 2nd ed. (London: Routledge, 2007), 187-199; Rebecca Schneider, Performing Remains: Art and War in Times of Theatrical Reenactment (New York: Routledge, 2011). 
their continuation." ${ }^{4}$ According to Louis Kriesberg, intractable conflicts exhibit four features: 1) they persist over long periods of time, including multiple generations; 2 ) they have, at some point, involved physical violence; 3) members from all associated groups perceive the conflict as irresolvable; and 4) these conflicts require the investment of massive financial, physical, mental, emotional, and psychological resources on the part of all those involved. ${ }^{5}$ It is not difficult to call to mind the cases that fit this bill: Israel/Palestine; Northern Ireland; Bosnia-Herzegovina; Kosovo; Cyprus; and, in many ways, the relationship between indigenous communities and settler colonial states. The intention of this article is not to describe in detail any one of these specific cases - as their complexity renders such a task impossible in this article. It will include, however, examples from some of these cases to illustrate what is ultimately a conceptual project of reframing the way the field thinks about intractability. Rather than adding to an already long list of "best practices" for responding to cases of intractability, this article asks to widen the lens through which those studying and seeking to intervene view these situations. As such, this article does not intend to provide concrete steps for conflict and atrocity prevention, but instead to redirect prevention efforts toward supporting interventions from within these societies that are already succeeding at re-writing the scripts that allow "intractable conflicts" to continue.

Before proceeding, it is important to delineate how and why I am eliding atrocity prevention and conflict prevention-two fields that are often perceived as separate, particularly by their practitioners. Traditionally, atrocity prevention is understood as necessary in the midst of largescale violence, while conflict prevention comes before and after that violence to address the underlying, structural issues that can lead or have led to mass atrocities. If one views atrocity prevention, however, not only as intervention at the height of crisis, but the actual attempt to prevent such crisis from occurring at all, then it inherently also involves addressing the structural factors that could lead to atrocity violence. ${ }^{6}$ In many cases, those underlying factors are related to the identity-based divisions one finds in seemingly intractable scenarios. As such, in this article I speak about conflict prevention and atrocity prevention as two sides of the same coin, given that it is difficult to name any so-called "intractable conflict" that has not experienced mass atrocity at some point.

Just a few synonyms that pop up from a Google search of "intractable" include "unmanageable," "out of control," and "impossible to cope with." This attitude of "impossibility" tinges not only external attempts to moderate intergroup conflict in these cases, but also limits the potential that those living within these societies see as solutions for these "out of control" situations. Because of this, I suggest in this article that, rather than conceptualizing these conflicts as somehow essentially intractable, it is more useful to perceive them as embodied enactments of scenarios of intractability, which I define below.

In this article, I argue that scenarios of intractability exhibit several specific characteristics, each of which increases the perception that identity-based divisions are an insurmountable and natural reality within their societal context. These characteristics are deeply ingrained because they have been essentialized through a long history of discursive and embodied actions that further division among groups, rather than offering opportunities for social cohesion and the dissipation of violent conflict. Furthermore, these divisions are often reinforced rather than mitigated through external conflict resolution and atrocity prevention efforts. I begin by defining scenarios of intractability and outlining their characteristics, focusing on the ways in which past conflict continues to present itself in the present and shape visions of the future. By recognizing these common characteristics, actors within scenarios of intractability can modify their own performances by engaging in what I call mitigating interventions-embodied or discursive actions emerging from within a given society that rewrite the script and push the scenario toward an alternative ending. This article outlines some potential mitigating interventions that have emerged within scenarios of intractability to

\footnotetext{
${ }^{4}$ Daniel Bar-Tal, "From Intractable Conflict through Conflict Resolution to Reconciliation: Psychological Analysis," Political Psychology 21, no. 2 (2000), 351-365.

${ }^{5}$ Louis Kriesberg, "Intractable Conflicts," in The Handbook of Interethnic Coexistence, ed. Eugene Weiner (New York: Continuum, 1998), 332-342.

${ }^{6}$ James Waller, Confronting Evil: Engaging Our Responsibility to Prevent Genocide (New York: Oxford University Press, 2016).
} 
Whigham

demonstrate how these interventions can transform the way these conflicts play out, mitigating the risk factors associated with mass atrocity violence in the process. Additionally, echoing the call of scholars like Bridget Moix to "turn atrocity prevention inside-out,"7 it calls for a reframing of atrocity prevention and conflict prevention/resolution/transformation as phenomena that can and perhaps should emerge from within these scenarios of intractability, rather than from external actors.

\section{Scenarios of Intractability}

I take the term scenario, as it is herein conceived, from performance studies scholar Diana Taylor, who defines a scenario as "a paradigmatic setup that relies on supposedly live participants, structured around a schematic plot, with an intended (though adaptable) end." ${ }^{8}$ They exist, she continues, as "culturally specific imaginaries-sets of possibilities, ways of conceiving conflict, crisis, or resolution-activated with more or less theatricality." In other words, scenarios are like social scripts that get played out repeatedly, with the specifics changing, but the underlying themes, actions, and players remaining the same..$^{10}$ Scenarios include discourse and are impacted by, for instance, historical narratives-that is, interpretations of the past presented through the written or spoken word. Analyzing these cases of conflict as scenarios rather than only narratives, however, allows us to attend to the spoken and unspoken, the discursive and the embodied, ways in which identity-based division plays out in cases of so-called intractable conflict. Herein lies a central contribution of performance studies to genocide studies: it forces us to understand genocide and violence more broadly as an embodied phenomenon, which is certainly enacted through words and narratives, but also through daily social interactions, public policy, the organization of public space, and the flow of capital. Richard Schechner, one of the founders of the field, describes performance as "restored behavior," or the embodied actions that are played and replayed in our lives, whether they be in the context of a theatrical production or one's daily routine. ${ }^{11}$ These embodied actions or interactions take place within the context of a scenario, and depending on that scenario, each action can take on a different valence. Understanding the rules of the scenarios playing out within deeply divided societies both offers a new lens for comprehending these conflicts and opens up opportunities for "flipping the script," thereby creating alternative pathways that might break out of these scenarios that get performed and reperformed in more or less similar ways on a daily basis.

I posit, then, that a scenario of intractability is one in which the "script" of identity-based division and conflict has become so central to daily interactions and discourse, as well as social, political, and economic structures, that it is perceived as natural, immutable, and irreversible. In scenarios of intractability, division among identity groups is so deeply ingrained that it has become part of what Pierre Bourdieu refers to as habitus-the structures and presuppositions within a society that underly all actions and discourse, but which are so taken for granted that they are assumed to be natural and inalterable, even if they are, in fact, not. ${ }^{12}$ Habitus shapes what is perceived to be possible. This sense of conflict as habitus is supported in certain of the conflict resolution literature. For instance, Howard Gadlin writes, "When caught up in an intractable conflict, [...] it often appears as if it is the conflict directing the disputants rather than the other way around."13 Adrian Guelke describes

\footnotetext{
${ }^{7}$ Bridget Moix, "Turning Atrocity Prevention Inside-Out: Community-Based Approaches to Preventing, Protecting, and Recovering from Mass Violence," Genocide Studies and Prevention 9, no. 3 (2016), 59-69.

${ }^{8}$ Diana Taylor, The Archive and the Repertoire: Performing Cultural Memory in the Americas (Durham: Duke University Press, 2003), 13.

${ }^{9}$ Ibid.

${ }^{10}$ In some ways, scenarios are related to the concept of another scholar frequently evoked in Performance Studies, Erving Goffman $(1959,1986)$. His theory of social "frames" in the "presentation of self in everyday life" begins to describe this phenomenon. Frames, however, describe more the context in which actions take place. Scenario thinking provides a lens for looking at the context, actors, actions, and histories all at once.

${ }^{11}$ Richard Schechner, Performance Studies: An Introduction (New York: Routledge, 2013).

${ }^{12}$ Pierre Bourdieu, Outline of a Theory of Practice, trans. Richard Nice (Cambridge, UK: Cambridge University Press, 1977); Pierre Bourdieu, The Logic of Practice (Stanford: Stanford University Press, 1990).

${ }^{13}$ Howard Gadlin, “Rethinking Intractability: A New Framework for Conflict,” Negotiation Journal 29, no. 1 (January 2013), 103.
} 
deeply divided societies as existing within a "force field" that exacerbates and reproduces internal divisions. ${ }^{14}$ This force field metaphor connotes both the insular, self-perpetuating nature of these scenarios, but perhaps also alludes to the difficulty of external intervention. The force field of these deep divisions makes it more challenging for disinterested actors both to enter into the scenario and to provide the tools for resolving the divisions. In scenarios of intractability, the habitus is such that identity divisions among groups are perceived as not only essential, but also as the source of an unbridgeable gulf. Furthermore, the source of conflict between these groups is understood both as historical-having some former precedent that justifies the conflict-and as irreversible-extending far into the future, without much hope for resolution.

The great hope of seeing cases of intractable conflict instead as scenarios of intractability is that participants within these scenarios can begin to understand the underlying scripts that surround them, as well as the roles that they are asked to play in reinforcing those scripts. By making obvious the components that go into creating scenarios of intractability, their constructed nature becomes more evident. As a result, it presents participants with opportunities to "flip the script" the roles that habitus would have them play and introduce new dialogue and embodied actions into these scenarios that can lead to alternative endings. Importantly, these new interventions could emerge from within the "force field" of the scenario, rather than relying solely on interventions from without, in the form of the external mediation tactics or preventive diplomacy efforts that are often advocated. ${ }^{15}$ In many ways, thinking about intractable conflicts as scenarios of intractability echoes a call by some scholars to move to a more systems-based understanding of these cases. ${ }^{16}$ Such an approach understands these conflicts "as dynamic, complex systems,"17 or, as Coleman puts it, "living entities made up of a variety of interdependent and interactive elements, nested within other, interestingly complex entities." ${ }^{18}$ A complex, systems-based approach to these cases, then, allows interested parties "to stop approaching conflicts as problems that need to be fixed [...] and instead think of them as systems with underlying dynamics that need to shift."19

From this perspective, a scenario paradigm aligns in many ways with a systems paradigm in that it captures the vast complexity of actors, institutions, and practices that contribute to social division. This systems approach to conflict resolution, however, has until now been developed by scholars from fields like economics, political science, biology, and other fields that rely largely on quantitative methodologies. ${ }^{20} \mathrm{~A}$ performance studies approach via scenario thinking expands the focus from quantifiably measurable data sets to the qualitative analysis of embodied practices, historical narratives, and daily social interaction as key components in understanding and shifting the dynamics that underly division. Those working within a systems paradigm are also still susceptible to the notion that the key to conflict resolution comes from without. For instance, Gadlin, citing Coleman, asserts that "people in intractable conflicts are often trapped in those conflicts and need help to get free." ${ }^{21}$ Thinking in terms of scenarios of intractability, on the other hand, opens the door to explore what mitigating interventions are already taking place within the scenario itself. The question then becomes not what can be done from the outside to "fix" the problems of another society, but rather how those mitigating interventions can be supported and amplified to lead to more lasting change created from within.

Before delving into the ways scenarios of intractability can and have been mitigated, I begin by highlighting four characteristics that can be found across these scenarios that increase the risk

\footnotetext{
${ }^{14}$ Guelke, Politics in Deeply Divided Societies.

${ }^{15}$ Carnegie Commission on Preventing Deadly Conflict, "Preventing Deadly Conflict: Final Report" (New York: Carnegie Corporation of New York, 1997).

${ }^{16}$ Peter T. Coleman, The Five Percent: Finding Solutions to Seemingly Impossible Conflicts (New York: Public Affairs, 2011); Gadlin, Rethinking Intractability; Dan Jones, "Wars Without End," Nature 519 (March 12, 2015), 148-150; Robert Ricigliano, Making Peace Last: A Toolbox for Sustainable Peacebuilding (New York: Routledge, 2012).

${ }^{17}$ Jones, Wars Without End, 149.

${ }^{18}$ Quoted in Gadlin, Rethinking Intractability, 103.

${ }^{19}$ Jones, Wars Without End, 150.

${ }^{20}$ Jones, Wars Without End.

${ }^{21}$ Gadlin, Rethinking Intractability, 110.
} 
Whigham

for identity-based violence, providing cursory examples from specific cases to illustrate these characteristics. These illustrations are admittedly oversimplified and brief. They are intended merely as a means of illuminating the theoretical underpinnings of the article, rather than providing an in-depth case study of any one instance of a scenario of intractability.

\section{Competitive Victimhood}

First, scenarios of intractability are supported by an underlying logic of us-them thinking-a necessary precondition for identity-based violence. Scenarios of intractability enhance us-them divisions, allowing each group involved to depict the in-group as victims and the out-group as victimizers. This feature of scenarios of intractability pushes all groups involved to focus on the assignment of blame/responsibility, rather than attempting to forge a new path forward in which opposing groups can co-exist. As such, scenarios of intractability encourage what Noor, Brown, and Prentice refer to as a subjective evaluation of past violence..$^{22}$ Each group involved chooses to view the violence only from its own perspective. When a group has perpetrated violence, subjective evaluation encourages them to justify that violence either as a defense against an existential threat from the other group or as somehow righteously motivated. When it comes to victimization, subjective evaluation pushes groups to see only their own suffering, rather than how other groups may have also suffered, albeit in different ways.

Another result of this characteristic of scenarios of intractability is the fostering of competitive victimhood. ${ }^{23}$ Noor et al. write:

This concept refers to each group's effort to claim that it has suffered more than the outgroup. Moreover, this competition over the quantity of suffering also implies some dispute over the illegitimacy of suffering. That is, "not only have we suffered more than you, but it is decidedly unfair that we have." ${ }^{24}$

Competitive victimhood (CV) keeps division going, as it serves as an undergirding source of enduring conflict, even in periods in which physical violence has ceded. Noor et al. write that $\mathrm{CV}$ directly contributes "to conflicts' continuation, escalation, and the impediment of potential resolutions." ${ }^{25}$ As groups seek to underscore their own suffering, framing it as either the only true example or, at the very least, the worst example of suffering, CV prevents the development of empathy, which many argue to be an essential component of reconciliation or, at the very least, the prevention of future violence. ${ }^{26}$

Competitive victimhood can be found in most, if not all, of the scenarios of intractability listed at the beginning of this article, but one of the most obvious examples of this first characteristic of scenarios of intractability comes from Israel/Palestine. In this scenario, both Jewish Israelis and Palestinians cast themselves in the role of victims who have suffered and continue to suffer at the hands of the other group. To varying degrees, members from both sides have been responsible for the perpetration of violence, but each frames their use of violence as defensive and necessary, while explaining the other group's use of violence as excessive and as an existential threat. Furthermore,

\footnotetext{
${ }^{22}$ Masi Noor, Rupert James Brown, and Garry Prentice, "Prospects for Intergroup Reconciliation: Social Psychological Predictors of Intergroup Forgiveness and Reparation in Northern Ireland and Chile," in Social Psychology of InterGroup Reconciliation: From Violent Conflict to Peaceful Co-Existence-Going Beyond Victimization, Guilt, and Distrust, eds. Arie Nadler, Thomas Malloy, and Jeffrey D. Fisher (Oxford: Oxford University Press, 2008), 97-114; Masi Noor, Rupert Brown, and Garry Prentice, "Precursors and Mediators of Intergroup Reconciliation in Northern Ireland: A New Model," British Journal of Social Psychology 47 (2008), 481-495.

${ }^{23}$ Noor et al., Prospects for Intergroup Reconciliation; Noor et al., Precursors and Mediators.

${ }^{25}$ Masi Noor et al., “When Suffering Begets Suffering: The Psychology of Competitive Victimhood Between Adversarial Groups in Violent Conflict," Personality and Social Psychology Review 16, no. 4 (2012), 351.

${ }^{26}$ Jodi Halpern and Harvey M. Weinstein, "Rehumanizing the Other: Empathy and Reconciliation," Human Rights Quarterly 26 (2004), 561-583; Donald Walker and Richard L. Gorsuch, "Dimensions Underlying Sixteen Models of Forgiveness and Reconciliation," Journal of Psychology and Theology 32, no. 1 (2004), 12-25; Arie Nadler and Ido Liviatan, "Intergroup Reconciliation: Effects of Adversary's Expressions of Empathy, Responsibility, and Recipients' Trust," Personality and Social Psychology Bulletin 32, no. 4 (2006), 459-470.
} 
both groups have historical experiences of trauma-the Holocaust for Jewish Israelis and the Naqba for Palestinians-that continue to frame their understandings of the present and serve as a source of competitive victimhood. This appeal to victimhood on both sides increases at least partly due to what Pilecki and Hammack describe as the empowering potential that comes from victim status. ${ }^{27}$ They write that, in their study, victimhood narratives "allowed Palestinians to explain their low status within the conflict by framing it as a product of Jewish Israeli aggression." 28 Likewise, they write that Jewish Israeli participants used a similar narrative "to reestablish moral status while also engendering sympathy and understanding for Jewish Israeli actions." ${ }^{29}$ For both sides, then, victim status is used to establish a position of power and justification, rather than to assert some self-deprecatory or self-defeating feeling at the heart of the in-group's identity.

\section{Mutually Exclusive Historical Narratives}

Second, in scenarios of intractability, historical narratives-that is, the stories each group tells itself about its past and uses to justify its actions in the present-rest on a claim of mutual exclusivity. The narratives of each group do not allow for disagreement, contention, or alternative perspectives. Most important, they do not allow for the existence of the out-group's narrative or understanding of the past. The very presence of the out-group's narrative is perceived not only as an attack on the in-group, but as an existential threat to the in-group's existence. Social psychologist Daniel Bar-Tal, one of the foremost experts on intractable conflicts, writes that historical narratives within cases of intractable conflict "do not intend to provide an objective history of the past, but tell about the past as it is functional to the society's present existence, especially given its confrontation with the rival society." ${ }^{30}$ He continues, "Thus, they create a socially constructed narrative that has some basis in actual events but is biased, selective, and distorted in ways that meet the society's present needs." 31 I would only add that, although these narratives are subjective and selective, they present themselves as objective and total, hence their mutual exclusivity.

In his essay "Public Memory in Place and Time," philosopher Edward S. Casey lays out a fourpart typology of memory. ${ }^{32}$ Individual memory describes the recollections that an individual has about events she has experienced directly. Social memory is his designation for "memory held in common by those who are affiliated either by kinship ties, by geographical proximity in neighborhoods, cities, and other regions, or by engagement in a common project" ${ }^{33}$-that is, by members of a given identity group. Collective memory occurs when "different persons, not necessarily known to each other at all, nevertheless recall the same event"34-that is, when an event exceeds the frame of any one identity group, creating new opportunities for "plural remembering." 35 The final category, public memory, emerges when these group memories bring people together in the public sphere. Public memory occurs through shared practices of memorialization and commemoration, which create new collectives, at least in the moment of togetherness.

Elsewhere, I write about the political potential that exists through public memory-the power and agency that can emerge through groups of people, once isolated, coming together around experiences of the past. ${ }^{36}$ Historical narratives in scenarios of intractability do not allow for the

\footnotetext{
${ }^{27}$ Andrew Pilecki and Phillip P. Hammack, “'Victims' Versus ‘Righteous Victims': The Rhetorical Construction of Social

Categories in Historical Dialogue Among Israeli and Palestinian Youth," Political Psychology 35, no. 6 (2014), 813-830.

${ }^{28}$ Pilecki and Hammack, "“Victims' Versus 'Righteous Victims"' 823.

${ }^{29}$ Ibid.

${ }^{30}$ Daniel Bar-Tal, “Sociopsychological Foundations of Intractable Conflicts," American Behavioral Scientist 50, no. 11 (2007), 1436.

${ }^{31}$ Ibid.

${ }^{32}$ Edward Casey, "Public Memory in Place and Time," in Framing Public Memory, ed. Kendall R. Phillips (Tuscaloosa: University of Alabama Press, 2004), 17-44.

${ }^{33}$ Ibid., 21.

${ }^{34}$ Ibid., 23.

${ }^{35}$ Ibid.

${ }^{36}$ Kerry Whigham, "Performing Prevention: Civil Society, Performance Studies, and the Role of Public Activism in Genocide Prevention," in Reconstructing Atrocity Prevention, eds. Sheri P. Rosenberg, Tibi Galis, and Alex Zucker
} 
breaking down of walls and divisions necessary for public memory to emerge. In fact, they do not even allow for collective memory, because they fail to acknowledge the realities and emotions of any group other than the in-group. Historical narratives in these scenarios belong only to the realm of social memory. They exist within the framework of one identity community. At the same time, however, these narratives claim to be collective, public, and authoritative. They do not make space for alternative understandings of the past.

In the United States, for instance, historical violence against Indigenous communities is viewed completely differently by the US government and the Indigenous communities themselves. Although most Indigenous communities understand colonialism and the historical and continuing dispossession of their land as an act of genocide, the US government (like many other settler colonial governments) prefers to see such violence and dispossession as a reality of the past that is unfortunate but is no longer up for debate in contemporary political discourse. There has been little real conversation regarding land restitution in the United States, nor is there likely to be in the future. Furthermore, the US government depicts Indigenous communities that make claims for land restitution as unrealistic and unreasonable. There is no room for the co-existence of these two narratives in the discussion.

\section{Past Violence as Justification for Present and Future Violence}

Third, in scenarios of intractability, actors recall past conflicts as a continual justification for actionincluding discrimination, violation of human rights, and violent conflict-in the present. I have already presented that one of the key features of scenarios of intractability is that they frame the in-group as victims of the out-group. Through this third feature, the in-group frames itself not only as victims, but as what Pilecki and Hammack refer to as righteous victims. ${ }^{37}$ That is, in scenarios of intractability, the in-group frames itself as the protagonist and justifies its use of violence and discrimination based on a right to self-defense and self-preservation. Within these scenarios, the in-group sees itself as under an existential threat from the out-group(s). Under these conditions, their use of violence is presented as righteous, while the victimization of the out-group is equally justified, given that, were it not for the in-group's actions, the out-group would surely attack and eliminate the in-group.

A prime example of this behavior comes from Serbia during the civil wars that subsumed the Balkans in the 1990s. In the years preceding this conflict-and indeed still today-leaders from Serbia and Republika Srpska constantly evoked the 1389 Battle of Kosovo in public speeches and discourse. During this historic battle, Serbian Prince Lazar Hrebeljanović and his forces faced the invading Ottoman Empire in battle and ultimately lost (though the Ottomans faced losses, as well). Today, Serb nationals evoke this historic battle as a means of justifying violence against Bosnian Muslims, who, in this narrative, are framed as the invading Ottomans. Similarly, Serb nationalists also speak of the ultranationalist Croatian Ustasha and their actions against Serbs during World War II. The Ustasha, which was aligned with the Nazis, persecuted not only Jewish people, but also Serbs within Croatian territory. Ethnic Serbs faced genocidal violence at the hands of the Ustasha during the 1940s. Today, Serb nationalists use the memory of this violence to justify violence and discrimination against ethnic Croats.

Both these instances are examples of what Vamik Volkan calls time collapse, through which "the interpretations, fantasies and feelings about a past shared trauma commingle with those pertaining to a current situation." ${ }^{\prime 38}$ Volkan points out that, in cases of time collapse, subjects may be very well able to understand intellectually that an historic event is not connected to the present moment, but the emotional tie between the past and present remains completely real. I would go even further to say that, in fact, public memory itself is an example of time collapse, through which actors tie the past with the present. Time collapse itself, then, is not always bad. Rather, it is how this collapse of time justifies division and violence where the true problems lie.

(New York: Cambridge University Press, 2015), 321-351; Kerry Whigham, "Remembering to Prevent: The Preventive Capacity of Public Memory," Genocide Studies and Prevention 11, no. 2 (2017), 53-71.

${ }^{37}$ Pilecki and Hammack, Victims' Versus 'Righteous Victims'.

${ }^{38}$ Vamik Volkan, Bloodlines: From Ethnic Pride to Ethnic Terrorism (New York: Farrar, Straus, and Giroux, 1997), 35. 


\section{A Divided Future}

Finally, scenarios of intractability paint a picture in which the only positive future is one without the out-group. Whether the out-group is annihilated or simply removed from the territory, these scenarios leave no room for a heterogenous society within which the in-group and out-group can peacefully co-exist. They do not only depict the in-group as justified and righteous; they depict the out-group as unreasonable, underhanded, and dangerous. Because of this, conversation and consensus do not appear as viable options. Furthermore, through framing the only viable future in this way, scenarios of intractability reinforce their own perpetuation. By default, the scenario must continually be replayed until this vision of the future without the out-group comes into being.

In all the scenarios of intractability I have enumerated earlier in this article, the stop-gap measure that has been implemented to deal with the reality that a significant portion of all groups cannot envision a peaceful future with the out-group in it has been territorial separation, as evidenced through, for example, the partitioning of the Gaza Strip and West Bank in Israel/Palestine; the separation of Catholic and Protestant neighborhoods in Northern Ireland; the "Balkanization" of former Yugoslavia and the stark segregation of most cities and towns across Bosnia-Herzegovina based on ethnic identity; and the demarcation of reservations for Native American populations in the United States. Even if these territorial divisions serve to dispel some (though certainly not all) violent conflict, they are completely unsustainable, as they allow for and even encourage identity divisions to continue. Even more, these territorial divisions promote the replaying of the scenarios of intractability that underly these divisions and that have contributed to violence in the past, putting these societies at continued risk for violent conflict in the present and future.

Underlying this entire reality is a dehumanizing impulse that categorizes the outgroup as immoral and, therefore, not worthy of the same rights and recognitions as the in-group. Ultimately, it is impossible to imagine a liberal democracy, ${ }^{39}$ free of violent conflict, that is not based at its core on the idea that every human has basic rights that are inherent to her humanity. Concomitantly, a democratic system must be based on the belief that all are equal before the law. According to Ernesto Verdeja, this basic form of mutual respect lies at the heart of bringing an end to scenarios of intractability ${ }^{40} \mathrm{He}$ writes: "Respect is not reserved for exceptional circumstances or for exceptional people; rather, it follows from recognizing others as having inherent rather than instrumental moral worth by virtue of being persons." ${ }^{41}$ Without nurturing an understanding that all human beings have not only moral worth, but an array of internationally agreed-upon rights that come along with their very humanity, it will be impossible to bring an end to scenarios of intractability like those discussed here.

To reiterate, scenarios of intractability are self-perpetuating scripts that shape embodied actions, discourse, and social interactions, increasing division among groups and keeping alive the tensions that can lead to further violence in the future. They are characterized by four qualities. Scenarios of intractability: 1) promote us-them thinking and competitive victimhood; 2) foreclose the possibility for alternative interpretations of the past; 3 ) recall the past to justify discrimination and/or outright violence; and 4) offer no option for coexistence in the future. Through the enactment of these characteristics, scenarios of intractability keep the affective force behind violent conflict alive, pushing participants within these scenarios to re-perform these conflicts at all social levels and on a daily basis. That is to say, these scenarios increase or sustain the risk factors that make mass atrocity violence more probable. ${ }^{42}$ When actors within these scenarios begin to recognize the

\footnotetext{
${ }^{39}$ By liberal democracy, I intend to highlight a system of government characterized by equal protection under the law within which the citizenry is governed by their own will. Just as with international human rights as a whole, this system of governance is admittedly aspirational and normative in nature, even if this platonic ideal does not or has not existed in reality.

${ }^{40}$ Ernesto Verdeja, Unchopping a Tree: Reconciliation in the Aftermath of Political Violence (Philadelphia: Temple University Press, 2009).

${ }^{41}$ Ibid., 30.

${ }^{42}$ Benjamin E. Goldsmith et al., "Forecasting the Onset of Genocide and Politicide: Annual Out-of-Sample Forecasts on a Global Dataset, 1988-2003," Journal of Peace Research 50, no. 4 (2013), 437-452; Barbara Harff, "No Lessons Learned
} 
way they play out, however, there exists the opportunity to "flip the script," offering mitigating interventions that can potentially lead to alternative, more positive endings.

\section{Mitigating Interventions, or "Flipping the Script"}

Mitigating interventions are embodied actions performed by participants within a scenario that divert it toward unexpected ends. In the cases of scenarios of intractability, mitigating interventions disrupt the four characteristics of scenarios I detail above. Rather than stoking the flames of identitybased division and, thus, heightening the risks associated with mass atrocity violence, mitigating interventions open the door for connection and cohesion across differences. In the process, they can help reduce some of the risk factors most commonly associated with mass atrocity violence, and consequently serve as a preventive force.

Currently there are numerous risk assessment models, all of which use quantitative and/or qualitative data to evaluate the risk that a society will fall victim to genocide or mass atrocity violence. The first was developed by Helen Fein ${ }^{43}$ over 25 years ago, and it has since been followed with models developed by Barbara Harff, ${ }^{44}$ Benjamin Goldsmith et al., ${ }^{45}$ the United Nations, ${ }^{46}$ the United States Holocaust Memorial Museum, ${ }^{47}$ and James Waller. ${ }^{48}$ Each of these models asserts that certain factors, when present, make identity-based violence or mass killing more likely (though not certain). Scenarios of intractability are particularly dangerous because they increase or maintain certain of the risk factors identified by these models, and thus make the recurrence of mass atrocity violence more likely. It is for this reason that one can consider the transformation of conflict in the scenarios as part and parcel with long-term atrocity prevention.

Traditionally, measuring the ability of any initiative or intervention to prevent genocide or mass atrocity violence has been a difficult task. Many believe that, in order to prove an intervention prevented mass violence, one would first have to prove that mass violence was inevitable and would have occurred were it not for a specific intervention. Of course, this standard of proof is too high, as proving a non-event is an impossibility. Instead, we must refocus our standards for evaluating preventive impact. ${ }^{49}$ There is large-scale agreement on the risk factors that often precede mass atrocity violence, and risk assessment models offer quantitative data as evidence that these factors are, in fact, predictive. These risk factors fall into a number of categories that impact a wide array of aspects of socio-political life, including factors related to governance, economic conditions, conflict history, and social fragmentation. ${ }^{50}$ Given the consensus that has developed around many of these risk factors, I assert that we can evaluate the preventive potential of any intervention by assessing its capacity to reduce any one of the risk factors associated with mass atrocity violence.

Scenario thinking helps to explain how these risk factors manifest through words and practice in social and political life. When participants within scenarios of intractability recognize these tropes, their constructed nature becomes evident, and participants can perform mitigating interventions that take the scenario in unexpected directions that can reduce, rather than reproduce, some of these risk factors. Recognizing these unexpected moments may be key in finding the successful means for emerging from the constantly looping cycle of intractability.

from the Holocaust? Assessing Risks of Genocide and Political Mass Murder since 1955," The American Political Science Review 97, no. 1 (2003), 57-73; Waller, Confronting Evil.

${ }^{43}$ Helen Fein, "Accounting for Genocide after 1945: Theories and Some Findings," International Journal on Group Rights 1, no. 2 (1993), 79-106.

${ }^{44}$ Harff, No Lessons Learned.

${ }^{45}$ Goldsmith et al, Forecasting the Onset of Genocide and Politicide.

${ }^{46}$ United Nations, "Framework of Analysis for Atrocity Crimes: A Tool for Prevention" (UN Office of the Special Advisers on Genocide Prevention and the Responsibility to Protect, 2014).

${ }^{47}$ United States Holocaust Memorial Museum, "Early Warning Project - United States Holocaust Memorial Museum," accessed June 21, 2017, https://www.ushmm.org/confront-genocide/how-to-prevent-genocide/early-warning-project.

${ }^{48}$ Waller, Confronting Evil.

${ }^{49}$ Whigham, Remembering to Prevent.

${ }^{50}$ Waller, Confronting Evil. 
Thus far in this article I have explored some of the ways in which scenarios of intractability increase or sustain the risk factors associated with atrocity violence. I now turn to how mitigating interventions can decrease these risk factors and open opportunities for breaking the loop inherent to scenarios of intractability. Scenarios of intractability produce discourses and practices of division that sustain the risk factors for mass violence, but mitigating interventions, to which I now turn, are performative in the way that, through their enactment, they diminish certain risk factors, making mass atrocity violence less likely.

Recognizing and Acknowledging

First, whereas scenarios of intractability promote us-them thinking that highlights the divisions among groups and encourages competitive victimhood, mitigating interventions can foster empathy for the suffering of others as a key aspirational value. Typically, in scenarios of intractability, members of the in-group are resistant to acknowledge any responsibility for the violence perpetrated by their group, instead focusing on the suffering they themselves have experienced. This unwillingness to acknowledge the suffering of others sustains several risk factors associated with mass atrocity crimes. For instance, Waller's risk assessment mode ${ }^{51}$ points out two indicators of risk, in particular, that are strengthened by an unwillingness to engage with the suffering of others. First, denial of others' suffering strengthens identity-based social divisions, given that denial and competitive victimhood only fortifies in-group/out-group distinctions. Second, it can also cultivate what Waller calls a "legacy of vengeance or group grievance," whereby the group whose suffering goes unacknowledged finds it impossible to make inroads into new relationships with the outgroup because resentment toward that group is too high.

Mitigating interventions start from a basis of mutual respect, that is, as Verdeja puts it, "the reciprocal recognition of the moral worth and dignity of others." ${ }^{52}$ Mutual respect is, at its core, empathic, because it supposes that all individuals, regardless of their identity, are subject to the same rights and responsibilities, and when those rights are violated for one group, it is an affront to all groups. Rather than starting from a place of competitive victimhood, mitigating interventions acknowledge the suffering of others. Importantly, this does not necessarily mean that groups deny their own suffering-only that they permit that other groups have also suffered.

Acknowledgment of the suffering of others is often a key opening step in improving relations among conflicting groups and breaking the cycle of scenarios of intractability. Lack of acknowledgment of all groups' experiences can lead to a social imbalance that inhibits peacebuilding efforts and encourages social fragmentation and vengeful feelings. Acknowledgment of the suffering of others coincides with a recognition of the out-group as moral agents who have had their rights violated.$^{53}$ As Elazar Barkan puts it, "The road to reconciliation begins with acknowledgment." ${ }^{54}$ This recognition of the other group's pain, however, requires some level of empathy, and empathy is never a given in these situations. One study conducted by Cehajić and Brown finds that "lack of empathy and perspective taking" is one of the key factors that prevents groups from acknowledging their own misdeeds in the aftermath of violent conflict. ${ }^{55}$ Too often, it is difficult to develop empathy for the out-group because high levels of social fragmentation prevent the in-group from ever being in contact with out-group members. As a result, many ingroup members hear only the divisive rhetoric of intractability repeated back to them in an echo

\footnotetext{
${ }^{51}$ Ibid.

${ }^{52}$ Verdeja, Unchopping a Tree, 3.

${ }^{53}$ Elazar Barkan, The Guilt of Nations: Restitution and Negotiating Historical Injustices (New York: W. W. Norton \& Company, 2000); Elazar Barkan, "Restitution and Amending Historical Injustices in International Morality," in Politics and the Past: On Repairing Historical Injustices, ed. John Torpey (Oxford: Rowman \& Littlefield Publishers, Inc., 2003), 91-102; Verdeja, Unchopping a Tree.

${ }^{54}$ Elazar Barkan, "Historical Reconciliation: Redress, Rights, and Politics," Journal of International Affairs 60, no. 1 (2006), 8.

${ }^{55}$ Sabina Cehajić and Rupert Brown, "Not in My Name: A Social Psychological Study of Antecedents and Consequences of Acknowledgment of In-Group Atrocities," Genocide Studies and Prevention 3, no. 2 (2008), 195-211.
} 
chamber. One method of generating empathy is through facilitating intergroup contact. ${ }^{56}$ Cehajić and Brown write, "Exposing perpetrators to the stories of survivors may facilitate perspective taking and, hence, empathy. In turn, this might increase psychological readiness to acknowledge the in-group's morally objectionable behavior." ${ }^{57}$ Contact theory has also generated critiques, however, which argue that intergroup contact often occurs in non-optimal conditions and over too short a period of time to have a lasting impact. ${ }^{58}$ One recent study finds that, in fact, contact may do very little to eliminate prejudice (discriminatory thoughts) toward others, but can do quite well at mitigating the enactment of those prejudices through discriminatory behavior. ${ }^{59}$

Aside from these issues relating to contact and empathy, the process of recognition must also be reciprocal for it to open the paths to reconciliation. The in-group may make the step of acknowledging the out-group's suffering, but this recognition must be met with a recognition in turn. In many scenarios of intractability, violence has been perpetrated by both sides. This said, the violence perpetrated or experienced by each side may not have been equal. Indeed, in some scenarios of intractability, the levels of violence are so imbalanced that it is difficult and, indeed, insensitive to even speak of equality of responsibility in any way. Because of this, it is important to point out that the reciprocal recognition I advocate is not one that promotes full-out forgiveness with no accountability. Rather, it is a recognition of each group's moral worth. Furthermore, it is a recognition that, should some form of accountability be necessary, this accountability will take place through the avenues of democratic institutions and the rule of law. Recognition, then, does not necessarily mean full recognition of what the out-group wants recognized. Instead, it is a requirement that each group recognizes the other's humanity, their rights, and their equality before the law.

An example of a mitigating intervention based on the precepts of recognition comes from the state of Maine in the United States. In 2012, five chiefs from the Wabanaki nation and the governor of Maine signed a mandate officially instituting the Maine Wabanaki-State Child Welfare Truth and Reconciliation Commission. The TRC was established in response to decades of abuse, during which Indigenous children from the Wabanaki people were taken from their families and placed in the state child welfare system. The result was decades of forced assimilation to non-Indigenous culture and the concomitant destruction of Native culture and community. According to the Commission's mandate, its goals were "to uncover and acknowledge the truth, create opportunities to heal and learn from that truth, and collaborate to operate the best child welfare system possible for Wabanaki children." ${ }^{60}$ Over the course of three years, the five commissioners, which included both Native and non-Native individuals, collected testimony and gathered information on the abuses experienced by the Wabanaki. Their findings were published in a final report in $2015 .{ }^{61}$ For

${ }^{56}$ Gordon W. Allport, The Nature of Prejudice (Garden City, NY: Doubleday, 1954); Rupert Brown and Miles Hewstone, "An Integrative Theory of Intergroup Contact," in Advances in Experimental Social Psychology, ed. Kendall R. Phillips (San Diego: Academic Press, 2005), 255-343; John F. Dovidio, Samuel L. Gaertner, and Kerry Kawakami, "Intergroup Contact and the Struggle for Social Justice," Group Processes \& Intergroup Relations 6 (2003), 5-21; Kevin Durrheim, and John Dixon, "Intergroup Contact and the Struggle for Social Justice," in Oxford Handbook of Social Psychology and Social Justice, ed. Phillip L. Hammack, Jr. (New York: Oxford University Press, 2018).

${ }^{57}$ Cehajić and Brown, Not in My Name, 206.

${ }^{58}$ John Dixon, Kevin Durrheim, and Colin Tredoux, "Beyond the Optimal Contact Strategy: A Reality Check for the Contact Hypothesis," American Psychologist 60, no. 7 (2005), 697-711; Elizabeth L. Paluck and Donald P. Green, "Prejudice Reduction: What Works? A Review and Assessment of Research and Practice," Annual Review of Psychology 60 (2009), 339-367; Ifat Maoz, "Contact and Social Change in an Ongoing Asymmetrical Conflict: Four SocialPsychological Models of Reconciliation-Aimed Planned Encounters between Israeli Jews and Palestinians," in Beyond the Prejudice Problematic, ed. John Dixon and Mark Levine (Cambridge, UK: Cambridge University Press, 2012), 269-285.

${ }^{59}$ Alexandra Scacco and Shana S. Warren, "Can Social Contact Reduce Prejudice and Discrimination? Evidence from a Field Experiment in Nigeria," American Political Science Review 112, no. 3 (August 2018), 654-677.

${ }^{60}$ Maine Wabanki- State Child Welfare Truth and Reconciliation Commission, Mandate, June 29, 2012, accessed November 7, 2019, http://www.mainewabanakitrc.org/wp-content/uploads/2013/04/TRCmandate.pdf.

${ }^{61}$ Maine Wabanaki-State Child Welfare Truth \& Reconciliation Commission, Beyond the Mandate: Continuing the Conversation (Herrmon, Maine: Maine Wabanaki-State Child Welfare Truth \& Reconciliation Commission, June 14, 2015), accessed November 7. 2019, http://www.mainewabanakitrc.org/wp-content/uploads/2015/07/TRC-ReportExpanded July2015.pdf. 
centuries, the relationship between Native nations and the United States government has played out as a scenario of intractability, characterized by all the four elements detailed earlier in this article. The Maine Wabanaki TRC is the first in US history in which a state government and a Native community agreed to come together to investigate the crimes that occurred. As such, it served as a powerful mitigating intervention that disrupted the traditional script of the scenario of intractability, principally through the act of recognition and acknowledgment of the Wabanaki's experience and the state's role in that experience.

\section{Allowing for Alternative Perspectives}

According to the UN's Framework of Analysis for Atrocity Crimes one risk indicator of atrocity violence is the presence of "ideologies based on the supremacy of a certain identity or on extremist versions of identity," ${ }^{62}$ and one way these supremacist ideologies are enacted in scenarios of intractability is through mutually exclusive historical narratives that do not allow room for alternative interpretations of the past. To counter the mutual exclusivity that characterizes scenarios of intractability, mitigating interventions open space for alternative understandings of the past to exist in parallel. These other versions of the past are not understood as an existential threat, but are instead indicators of an open public sphere, in which differences can be debated without leading to violent conflict. This statement requires several important caveats. Allowing alternative understandings of the past does not mean acknowledging the factuality of assertions that are empirically untrue. Nor does it mean that actors on either side should not try to influence, contest, and alter the historical narrative of the other side. Rather, what mitigating interventions can do is reshape the terms of the debate.

The goal for which all sides in scenarios of intractability should work is not one in which conflict disappears, but one in which violent conflict and the threat of such violence is eliminated. Mitigating interventions are not necessarily directed at eliminating conflict itself but allowing for differing perspectives to co-exist. The distinctions between these opposing narratives or perspectives-which are often important distinctions, especially from the subject position of each group-are negotiated in the public sphere through democratic discourse and healthy, agonistic debate. This reframing of conflict underscores that discord, in and of itself, is not a risk factor; rather, disagreement is dangerous when it is perceived as existentially threatening, and therefore worthy of response through physical violence. One of the most compelling recent arguments for this agonistic perspective of conflict in scenarios of intractability comes from Sarah Maddison. She writes, "Conflict is an essential democratic dynamic that may enable political actors to contest unjust situations, suggesting that there may need to be more rather than less conflict in order for political goals to be achieved." ${ }^{63}$ In all cases, it is not the existence of conflict itself that is the problem, but the kind of conflict. In response, Maddison argues for a model of political agonism, which is a mode of understanding and managing conflict as a reality that is constitutive of democracies and constructive in building more resilient societies, as long as that conflict remains civil and plays out within the realms of democratic institutions. Maddison writes that "the primary task of democracy is to convert antagonism into agonism and enemies into adversaries." ${ }^{64}$ Mitigating interventions, then, are ones that reframe the out-group not as an existential enemy, but as a contentious partner in constructing a democratic society together. As any multi-party political system in the world demonstrates, this is not always an easy process. All sides can still have completely different ideas about what occurred in the past, what their new society should look like, or how a collective future can be achieved. What is important, however, is that these disagreements play out in an open public sphere in which all groups have a seat at the table, and mitigating interventions allow that different views of the past do not foreclose interactions in the present.

As I mentioned, however, the need for mitigating interventions that allow for alternative understandings of the past to exist in parallel does not mean that empirical facts should be thrown

\footnotetext{
${ }^{62}$ United Nations, Framework of Analysis for Atrocity Crimes, 4.7.

${ }^{63}$ Sarah Maddison, Conflict Transformation and Reconciliation: Multi-Level Challenges in Deeply Divided Societies (London: Routledge, 2016), 26.

${ }^{64}$ Ibid., 53.
} 
out the window. For instance, there is no room in a democratic society to allow for genocide denial as a viable alternative perspective of the past. It is not based on factual truth, and it only serves to create division, as well as to devalue and dehumanize victims. As Verdeja puts it, truth telling in the aftermath of mass violence is both a right (of the victims) and a duty (to the victims) ${ }^{65}$ That said, Verdeja also contends that successful reconciliatory efforts should acknowledge three different aspects of truth. First, there is factual truth, which is understood and produced through investigations of evidence relating to acts of violence. Factual truth "is concerned with empirically ascertainable events and actions, as well as the concomitant rules and procedures of verification that these require." ${ }^{66}$ Phenomenological truth, on the other hand, describes the subjective and felt truth that is experienced and understood by individuals who have lived through large-scale violence. Finally, narrative truth describes how these other two components of truth get combined with current social and political realities to shape the stories we tell each other about the past. In scenarios of intractability, where perspectives and worldviews are typically understood as mutually exclusive and existentially threatened, to consider the reality that the out-group also has a phenomenological truth that, even if it may not be factually true, is no less true to them, subjectively speaking, is in and of itself a mitigating intervention. By granting the possibility that the out-group has a view of the world that, at least from its own perspective, is valid and truthful, a participant within the scenario of intractability derails a central characteristic that keeps the scenario on track. Recognizing this phenomenological truth also corresponds with the sort of recognition I mention above-a form of acknowledging the out-group's humanity, making them more willing and more likely to take a seat at the table to begin the difficult work of transforming enemies into adversaries.

An example of a mitigating intervention that literally and figuratively acknowledges that multiple truths can exist in parallel comes from Israel-Palestine. In 2001, in the midst of the Second Intifada, the Peace Research Institute in the Middle East (PRIME) brought together Palestinian and Israeli teachers to create a textbook that told the story of Israel-Palestine's most contentious historical moments from the perspective of both Jewish Israelis and Arab Palestinians. The teachers worked to craft the narratives, which recognized the factual, phenomenological, and narrative truths of both sides. These narratives were then placed side-by-side in a textbook so that, for instance, as the left side of the page talks about the "War of Independence," the right side of the page discusses "The Catastrophe [An-Nakbeh]." The teachers then began to use the book in their classrooms, and for many of their students, it was the first time they were exposed to the outgroup's understanding of the past. ${ }^{67}$ The mitigating intervention of this textbook thus disrupted one of the key characteristics of scenarios of intractability by showing that the narratives can, in fact, exist in parallel without necessarily taking away from identity of the in-group.

\section{Directing Negative Emotions to Positive Ends}

The UN's Framework also describes the "politicization of past grievances, tensions, or impunity" as a key risk indicator for atrocity crimes. ${ }^{68}$ Although the violent past is typically understood as a painful one, mitigating interventions are those that work against the tendency for scenarios of intractability to politicize that pain, transforming it into vengeance or revenge fantasies. It is without question that victims and people who have suffered during periods of mass violence have the right to feel pain-and feel it fully. I say this to emphasize that cultivating a culture that allows for antagonistic groups to move forward and build a society together is not synonymous with either a lack of memory or a lack of justice. Too often a rhetoric of "moving forward" or "moving on" is taken up by the groups who are responsible for causing the gravest amounts of suffering during periods of violence. Because of this, "moving forward" is typically a euphemism for two things: denialism and impunity. Both only play into and perpetuate scenarios of intractability,

\footnotetext{
${ }^{65}$ Verdeja, Unchopping a Tree.

${ }^{66}$ Ibid., 36.

${ }^{67}$ Sami Adwan and Dan Bar-On, “Shared History Project: A PRIME Example of Peace-Building Under Fire," International Journal of Politics, Culture and Society 17, no. 3 (2004), 513-521.

${ }^{68}$ United Nations, Framework of Analysis for Atrocity Crimes, 4.8.
} 
and neither should be cultivated or encouraged if what a society wants is actually to move forward together.

Elsewhere, I offer a strong critique not only of these calls to forget the past, but even of their realizability ${ }^{69}$ Although it may be easier for former perpetrators and bystanders to forget the violence that occurred, victims inevitably have a much harder time forgetting. Furthermore, as Verdeja ${ }^{70}$ and Mihaela Mihai ${ }^{71}$ rightly note, given that victims are the ones whose rights were violated, any newly established state has the responsibility to ensure that those victims are doubly recognized: assured that their rights will be respected by the new regime and that the rule of law is re-established, so that other's rights are not similarly violated. The rule of law, of course, cannot be fully established if those who perpetrated crimes are not brought to justice. ${ }^{72}$ Therefore, a state that claims to have reinstated the rule of law but has not developed any mechanisms for accountability is speaking out of both sides of its mouth.

This focus on the rule of law and democratic institution building is an essential aspect of the mitigating interventions that will truly transform scenarios of intractability to bring about a future in which more violence is not always on the horizon. This does not mean that negative emotions do not and should not exist in the context of post-atrocity societies on all sides of a conflict, but, as Mihai elucidates, that these emotions should be siphoned into appropriate avenues of redressthose that reinforce democratic institutions and the rule of law. ${ }^{73}$ Mihai points out that, in postatrocity contexts, two negative emotions tend to present themselves: resentment, or the negative feeling that stems from having experienced an injustice, and indignation, or the negative feeling that stems from witnessing an injustice done to others. In many cases, these feelings of resentment and indignation fuel a public discourse that justifies vengeance. One clear example Mihai gives is the show-trial and execution of Nicolae and Elena Ceașescu in the aftermath of the 1989 revolution in Romania. Another example can be seen in the historical narratives of post-civil war BosniaHerzegovina, in the ways that Serbs cite the Battle of Kosovo as a means of stoking feelings of resentment that can then be used to justify violence.

Mihai accurately points out that not only is it a futile task to try to eliminate these emotions in a post-atrocity context, but ignoring these emotions also ignores the opportunities that they present. Post-atrocity regimes can take advantage of these emotions to build democratic institutions and model the sorts of civic behavior that can lead to the reduction of risk factors for further atrocity violence. Rather than allowing resentment to fuel vengeful acts that deny the human rights and moral value of perpetrators-acts that only reinforce the script of the scenario of intractabilitydemocratic regimes can direct these emotions to support the rule of law. Through democratic judicial proceedings and the establishment of public policy that protects the rights of all individuals, these institutions model what Mihai calls "democratic appropriateness," meaning they acknowledge and offer redress for the injustices experienced by an individual or group without violating the human rights of another individual or group. ${ }^{74}$ This approach also recognizes that the resentment expressed by perpetrators who are brought to justice within a democratic framework is not, in fact, democratically appropriate-an understanding that is equally important to model within a post-atrocity context. ${ }^{75}$ Mitigating interventions of this sort acknowledge the legitimate injustices that have been experienced while at the same time ensuring these injustices are answered within a system that protects the human rights of all individuals.

It is admittedly more difficult to find examples of negative emotions being directed toward measures of justice and accountability in the midst of scenarios of intractability, but there is at least

\footnotetext{
${ }^{69}$ Whigham, Remembering to Prevent.

${ }^{70}$ Verdeja, Unchopping a Tree.

${ }^{71}$ Mihaela Mihai, Negative Emotions and Transitional Justice (New York: Columbia University Press, 2016).

${ }^{72}$ Verdeja, Unchopping a Tree.

${ }^{73}$ Mihai, Negative Emotions.

${ }^{74}$ Ibid., 69.

${ }^{75}$ Ibid., 77.
} 
one clear example where these negative emotions have been siphoned into democratic institutionbuilding, even as tensions remained high and the scripts of the scenario of intractability continued to perform itself. The Good Friday Agreement, which brought an end to decades of physical violence and fighting in Northern Ireland, was principally an instrument for the creation of several democratic institutions meant to maintain peaceful relations, transforming violent conflict taking place on the streets into political conflict taking place within the halls of government. Within Northern Ireland, it established the Northern Ireland Assembly, which operates on a model of cross-community voting, where both unionists and Irish nationalists must agree on measures to make them law, along with the Northern Ireland Executive, which operates on a basis of powersharing among conflicting groups. The Agreement also established democratic mechanisms for maintaining relations with both the United Kingdom and the Republic of Ireland. Admittedly, the peace negotiations in Northern Ireland and the subsequent accords did not emerge solely from within Northern Irish society but were also the result of external intervention. Furthermore, to argue that the institutions established by the Good Friday Agreement have led to a complete rewriting of the scenarios of intractability that still play out in Northern Ireland today is sadly overly optimistic, especially at the time of this writing, when the government of Northern Ireland is in a state of collapse, and as the potential of Brexit threatens to reignite violence in the region. It is also probable that the consociational peace agreement is at least partly responsible for institutionalizing the identity-based divisions at the root of the conflict-not a small caveat, to say the least. Twenty years after the passage of the agreements, however, conflicting groups have certainly succeeded at diminishing violent conflict, and have thus disrupted these scenarios in an important way.

Rewriting the "Ending"

Finally, scenarios of intractability always presume certain endings-endings in which one group succeeds and one group ceases to be, if not on an existential level, then at least within the daily lives and socio-political interactions of the other group. In scenarios of intractability, the future is bright only in as much as the out-group is not a part of it. In these scenarios, mitigating interventions propose alternative endings. Rather than depicting the success of one group and the elimination of another, they underscore shared values and common goals, presenting a future where all groups can co-exist.

One clear way of reshaping social relationships in these cases where public discourse paints a picture of a forever-divided future is through the creation of new, superordinate identities that override the identity markers that divide groups. Noor, Shnabel, Halabi, and Nadler, for instance, write that "encouraging members of conflicting groups to think about themselves as members of a common superordinate group, for example, to recategorize themselves as Americans instead of as Blacks and Whites, can reduce negative attitudes and biases toward out-group members." ${ }^{\prime 76}$ Forming superordinate identities can create solidarity across difference, providing new "roles" for those living within scenarios of intractability to assume.

An example of the power of superordinate identities comes from Tuzla, a Bosnian city that largely avoided the inter-ethnic conflict that had subsumed Bosnia-Herzegovina in the early 1990s, even as Bosnian Serb forces laid siege to the city and bombed it repeatedly. Throughout the conflict, this diverse city eschewed interethnic tensions by reinforcing their "Tuzlan" identity. According to Marshall Wallace, locals saw their identity as Tuzlans as being characterized by multiculturalism and an openness to difference. This identity based on multiculturalism and acceptance was reinforced through everyday practices. Residents of Tuzla attended and celebrated the religious holidays of all religious groups within the city, for instance. When Bosnian Serb bombs destroyed an Orthodox church in Tuzla, the city's mayor rallied citizens from all groups to participate in its reconstruction. The mayor also formed an orchestra during the war, and this musical group began composing new patriotic songs based on themes of togetherness and plurality. These new songs became a rallying cry for Tuzlans-a new repertoire that shunned ethno-nationalism for a citizenship

${ }^{76}$ Noor et al., When Suffering Begets Suffering, 363. 
based on inclusivity. During the height of inter-ethnic conflict in Bosnia-Herzegovina, the people of Tuzla rallied behind their shared identity, creating a new scenario based on overcoming collective hardship. As such, they were able to stave off the internecine conflicts that consumed the rest of the country. ${ }^{77}$

Importantly, however, emphasis on superordinate identities is not always the answer, and can even have negative effects. Stressing superordinate identities where subordinate identities constitute a salient part of the identity and daily interactions of individuals can lead individuals to emphasize and focus on the minor differences between groups. ${ }^{78}$ Because of this risk, Dovidio, Gaertner, and Saguy, offer two alternatives. ${ }^{79}$ First, individuals can focus on maintaining both super- and subordinate identities through a model where some common identity is acknowledged, but difference and pluralism is also celebrated within that model. Here, one can call to mind the common practice of hyphenated identities in the US American context. The researchers find, however, that this dual identity model only works in contexts where pluralism is a value that is celebrated. As such, within scenarios of intractability, this formation may not be easy to enact. The second possibility, however, is one that is reflected in basic social identity theory, as well. ${ }^{80}$ Rather than re-writing or imposing superordinate identities, groups can be brought together by having them work on common exercises or activities. By focusing on shared goals rather than trying to rewrite the saliency of identity, groups can come together across difference, while still maintaining the identity markers that are so important to them. A recent study by Scacco and Warren supports this idea. By bringing together Christian and Muslim participants to participate in a multi-week computer training workshop in a divided city in Central Nigeria, the researchers found that participants working with non-in-group partners demonstrated a marked decrease in discriminatory behavior toward the out-group (though there was no decrease in prejudicial beliefs) ${ }^{81}$ Importantly, identity was never explicitly addressed during the workshop; the participants were only working together toward the goal of learning how to use a computer. This option of transforming conflict by refocusing attention away from identity and toward a shared outward goal seems particularly apt in the case of scenarios of intractability. Rather than trying to rewrite identities, mitigating interventions can call for people from all identity groups to come together in the common project of building a society in which all their rights are respected and valued. This assertion is also supported by recent research that finds intractability to be more likely mitigated in situations where collectivist, rather than individualist, orientations are reinforced.$^{82}$

The people of Tuzla coming together to rebuild the bombed church is one example of such a mitigating intervention taking place at a social scale. The cross-community voting and powersharing agreements of the Good Friday Agreements are an example of it taking place at a national, political level. A third example of this comes from South Africa, where, for over four decades of Apartheid, South Africans lived within a scenario of intractability that favored white South Africans over Black, Coloured, and Asian South Africans. One mitigating intervention initiated by Archbishop Desmond Tutu and propagated by Nelson Mandela upon the return of democracy

\footnotetext{
${ }^{77}$ Marshall Wallace, "Tuzla, Bosnia: Cross-Ethnic Solidarity in the Face of Ethnic Cleansing," Case Study (Cambridge, MA: CDA Collaborative Learning Projects, 2002); Mary B. Anderson and Marshall Wallace, Opting Out of War: Strategies to Prevent Violent Conflict. (Boulder, CO: Lynne Rienner, 2013), 117-128.

${ }^{78}$ Volkan, Bloodlines; John F. Dovidio, Samuel L. Gaertner, and Tamar Saguy, "Another View of 'We': Majority and Minority Group Perspectives on the Common Ingroup Identity," European Review of Social Psychology 18 (2008), 296330.

${ }^{79}$ Dovidio, et al., Another View of 'We'.

${ }^{80}$ Muzafer Sherif, Experimental Study of Positive and Negative Intergroup Attitudes Between Experimentally Produced Groups: Robbers Cave Study (Tulsa: University of Oklahoma, 1954); Muzafer Sherif, "Superordinate Goals in the Reduction of Intergroup Conflict," American Journal of Sociology 63, no. 4 (1958), 349-356; Miles Hewstone and Rupert Brown, "Contact Is Not Enough: An Intergroup Perspective on the 'Contact Hypothesis,"' in Social Psychology and Society: Contact and Conflict in Intergroup Encounters, ed. Miles Hewstone and Rupert Brown (Cambridge, MA: Basil Blackwell, 1986), 1-44; Brown and Hewstone, An Integrative Theory.

${ }^{81}$ Scacco and Warren, Can Social Contact Reduce Prejudice and Discrimination?

${ }^{82}$ Peng Xiang et al., "Individualist-Collectivist Differences in Climate Change Inaction: The Role of Perceived Intractability," Frontiers in Psychology 10 (2019).
} 
was their characterization of South Africa as a "rainbow nation." The metaphor of the rainbow helped these leaders initiate a specific political project, in which people of all colors contributed to the beauty of the nation, but the true beauty came from their coming together. Many have argued, of course, that the rainbow imagery also served to cover up the legacies of violence that it sought to overcome, and there is great truth in this assertion. Nevertheless, the idea of a rainbow nation, along with its manifestation in a government structure that incorporated all races-when, in fact, it may have been possible for Mandela to form a government that excluded minority whites-served as a mitigating intervention that performed against the scenario of intractability that had been playing out for decades.

\section{Conclusion}

Labeling conflicts as intractable implies that this intractability is somehow an essential characteristic of the conflict itself. As such, there is a strong risk that the denomination serves to limit the scope of possible remedies that exist for transforming the conflict away from one characterized by violence and toward one facilitated through democratic institutions, the rule of law, and a healthy debate in an open public sphere. Participants within these scenarios replay the scripts of conflict that have been written and played out in the past. With each repetition, alternative endings seem less imaginable. The entire habitus of a society is shaped in relationship to conflict, and the realm of possibility becomes so constricted that any other way of being and feeling seems impossible. On the other hand, thinking in terms of scenarios of intractability recognizes that one central source for the continuing nature of the conflict is that division among groups has become, in many senses, a force of habit. Scenario thinking allows-indeed, forces-us to think beyond spoken discourse in understanding how conflict functions and reproduces itself. The spoken word and narratives certainly play a huge role in constructing scenarios of intractability, but so too do all other elements within a society, including geographical and/or architectural divisions, geopolitical realities, rituals and social practices, customs and traditions, and public policy initiatives. Indeed, a comprehensive strategy for preventing mass violence requires that we attend to all of these aspects that contribute to division.

Within the context of a scenario of intractability, mitigating interventions are actions by participants within the scenario that first highlight its constructed nature, thus making it appear less essentialized, and then offer alternative ways of being, thinking, and behaving within the scenario. Importantly, these mitigating interventions often come from within, rather than as a result of external intervention. As such, it may be better to conceive of them as intraventions. Enacting such mitigating intraventions is not easy, because one of the central aspects of a scenario of intractability is the way in which it makes such interventions feel either impossible or insufficient. Furthermore, for those of us working in conflict and atrocity prevention, it requires that we recognize that real, systemic prevention is much more about supporting domestic initiatives, rather than coming in from without with a bundle of recipes and best practices that "need to be" enacted. Additionally, in many of the scenarios of intractability I have discussed here, state actors and politicians are often working directly against the mitigation of risk because they benefit politically from keeping conflict and division alive. Because of this, it is often (unfairly) civil society that must be the first sector to offer these alternative examples of what undoing intractability may look like. The only hope for their actions to spread upward from the grassroots is through the contagious effect that public action can take. And it is here, in supporting and sustaining this growth, where the efforts of international actors can be much better exercised. For a scenario of intractability to be rewritten fully, these alternative scripts must be embraced by individuals and groups at all levels of society, across sectors and across group identities. It is only then that a totally new scenario can emergeone based not on division and violent conflict, but on creating a pluralistic society with a vibrant public sphere together.

\section{Bibliography}

Adwan, Sami and Dan Bar-On. "Shared History Project: A PRIME Example of Peace-Building Under Fire." International Journal of Politics, Culture and Society 17, no. 3 (2004), 513-521. Doi: 10.1023/b:ijps.0000019616.78447.5e 
Allport, Gordon W. The Nature of Prejudice. Garden City, NY: Doubleday, 1954.

Anderson, Mary B. and Marshall Wallace. Opting Out of War: Strategies to Prevent Violent Conflict. Boulder: Lynne Rienner, 2013.

Austin, John L. How to Do Things with Words. Cambridge, MA: Harvard University Press, 1962.

Barkan, Elazar. "Historical Reconciliation: Redress, Rights, and Politics." Journal of International Affairs 60, no. 1 (2006), 1-15.

"Restitution and Amending Historical Injustices in International Morality." In Politics and the Past: On Repairing Historical Injustices, edited by John Torpey, 91-102. Oxford: Rowman \& Littlefield Publishers, Inc., 2003.

The Guilt of Nations: Restitution and Negotiating Historical Injustices. New York: W. W. Norton \& Company, 2000.

Bar-Tal, Daniel. "From Intractable Conflict through Conflict Resolution to Reconciliation: Psychological Analysis." Political Psychology 21, no. 2 (2000), 351-365. Doi: 10.1111/0162895x.00192

-------. "Sociopsychological Foundations of Intractable Conflicts." American Behavioral Scientist 50, no. 11 (2007), 1430-1453. Doi: 10.1177/0002764207302462

Bourdieu, Pierre. Outline of a Theory of Practice. Translated by Richard Nice. Cambridge, UK: Cambridge University Press, 1977.

--------. The Logic of Practice. Stanford, Calif.: Stanford University Press, 1990.

Brown, Rupert and Miles Hewstone. "An Integrative Theory of Intergroup Contact." In Advances in Experimental Social Psychology, edited by Kendall R. Phillips, 255-343. San Diego: Academic Press, 2005. Doi: 10.1016/s0065-2601(05)37005-5

Butler, Judith. Excitable Speech: A Politics of the Performative. New York: Routledge, 1997.

--------. "Performative Acts and Gender Constitution: An Essay in Phenomenology and Feminist Theory." In The Performance Studies Reader, edited by Henry Bial, 2nd ed., 187-199. London: Routledge, 2007.

Carnegie Commission on Preventing Deadly Conflict. "Preventing Deadly Conflict: Final Report." New York: Carnegie Corporation of New York, 1997.

Casey, Edward. "Public Memory in Place and Time." In Framing Public Memory, edited by Kendall R. Phillips, 17-44. Tuscaloosa: University of Alabama Press, 2004.

Cehajić, Sabina and Rupert Brown. "Not in My Name: A Social Psychological Study of Antecedents and Consequences of Acknowledgment of In-Group Atrocities." Genocide Studies and Prevention 3, no. 2 (2008), 195-211. Doi: 10.1353/gsp.2011.0017

Coleman, Peter T. The Five Percent: Finding Solutions to Seemingly Impossible Conflicts. New York: Public Affairs, 2011.

Dixon, John, Kevin Durrheim, and Colin Tredoux. "Beyond the Optimal Contact Strategy: A Reality Check for the Contact Hypothesis." American Psychologist 60, no. 7 (2005), 697-711. Doi: 10.1037/0003-066X.60.7.697

Dovidio, John F., Samuel L. Gaertner, and Kerry Kawakami. "Intergroup Contact and the Struggle for Social Justice." Group Processes \& Intergroup Relations 6 (2003), 5-21.

Dovidio, John F., Samuel L. Gaertner, and Tamar Saguy. "Another View of 'We': Majority and Minority Group Perspectives on the Common Ingroup Identity." European Review of Social Psychology 18 (2008), 296-330. Doi: 10.1080/10463280701726132

Durrheim, Kevin and John Dixon. "Intergroup Contact and the Struggle for Social Justice." In Oxford Handbook of Social Psychology and Social Justice, edited by Phillip L. Hammack, Jr. New York: Oxford University Press, 2018. Doi: 10.1093/oxfordhb/9780199938735.013.15

Fein, Helen. "Accounting for Genocide after 1945: Theories and Some Findings." International Journal on Group Rights 1, no. 2 (1993), 79-106. Doi: 10.1163/157181193x00013

Gadlin, Howard. "Rethinking Intractability: A New Framework for Conflict." Negotiation Journal 29, no. 1 (January 2013), 99-117. Doi: 10.1111/nejo.12007

Goffman, Erving. Frame Analysis: An Essay on the Organization of Experience. Boston, MA: Northeastern University Press, 1986.

---------. The Presentation of Self in Everyday Life. Norwell, MA: Anchor Press, 1959. 
Goldsmith, Benjamin E., Charles R. Butcher, Dimitri Semenovich, and Arcot Sowmya. "Forecasting the Onset of Genocide and Politicide: Annual Out-of-Sample Forecasts on a Global Dataset, 1988-2003." Journal of Peace Research 50, no. 4 (2013), 437-452. Doi: 10.1177/0022343313484167

Guelke, Adrian. Politics in Deeply Divided Societies. Cambridge, UK: Polity, 2012.

Halpern, Jodi and Harvey M. Weinstein. "Rehumanizing the Other: Empathy and Reconciliation." Human Rights Quarterly 26 (2004), 561-583. Doi: 10.1353/hrq.2004.0036

Harff, Barbara. "No Lessons Learned from the Holocaust? Assessing Risks of Genocide and Political Mass Murder since 1955." The American Political Science Review 97, no. 1 (2003), 57-73. Doi: $10.1017 / \mathrm{s} 0003055403000522$

Hewstone, Miles and Rupert Brown. "Contact Is Not Enough: An Intergroup Perspective on the 'Contact Hypothesis."' In Social Psychology and Society. Contact and Conflict in Intergroup Encounters, edited by Miles Hewstone and Rupert Brown, 1-44. Cambridge, MA: Basil Blackwell, 1986.

Jones, Dan. “Wars Without End." Nature 519 (March 12, 2015), 148-150.

Kriesberg, Louis. "Intractable Conflicts." In The Handbook of Interethnic Coexistence, edited by Eugene Weiner, 332-342. New York: Continuum, 1998.

Lijphart, Arend. "Typologies of Democratic Systems." Comparative Political Studies 1 (April 1968), 3-44.

Maddison, Sarah. Conflict Transformation and Reconciliation: Multi-Level Challenges in Deeply Divided Societies. London: Routledge, 2016. Doi: 10.4324/9781315884509

Maine Wabanaki-State Child Welfare Truth \& Reconciliation Commission. Beyond the Mandate: Continuing the Conversation. Herrmon, Maine: Maine Wabanaki-State Child Welfare Truth \& Reconciliation Commission, June 14, 2015. Accessed November 7. 2019. http://www. mainewabanakitrc.org/wp-content/uploads/2015/07/TRC-Report-Expanded July2015. pdf.

--------. Mandate. June 29, 2012. Accessed November 7, 2019. http://www.mainewabanakitrc.org/ wp-content/uploads/2013/04/TRCmandate.pdf.

Maoz, Ifat. "Contact and Social Change in an Ongoing Asymmetrical Conflict: Four SocialPsychological Models of Reconciliation-Aimed Planned Encounters between Israeli Jews and Palestinians." In Beyond the Prejudice Problematic, edited by John Dixon and Mark Levine, 269-285. Cambridge, UK: Cambridge University Press, 2012. Doi: 10.1017/ cbo9781139022736.016

Mihai, Mihaela. Negative Emotions and Transitional Justice. New York: Columbia University Press, 2016.

Moix, Bridget. "Turning Atrocity Prevention Inside-Out: Community-Based Approaches to Preventing, Protecting, and Recovering from Mass Violence." Genocide Studies and Prevention 9, no. 3 (2016), 59-69. Doi: 10.5038/1911-9933.9.3.1313

Nadler, Arie and Ido Liviatan. "Intergroup Reconciliation: Effects of Adversary's Expressions of Empathy, Responsibility, and Recipients' Trust." Personality and Social Psychology Bulletin 32, no. 4 (2006), 459-470. Doi: 10.1177/0146167205276431

Noor, Masi, Rupert James Brown, and Garry Prentice. "Prospects for Intergroup Reconciliation: Social Psychological Predictors of Intergroup Forgiveness and Reparation in Northern Ireland and Chile." In Social Psychology of Inter-Group Reconciliation: From Violent Conflict to Peaceful Co-Existence-Going Beyond Victimization, Guilt, and Distrust, edited by Arie Nadler, Thomas Malloy, and Jeffrey D. Fisher, 97-114. Oxford: Oxford University Press, 2008. Doi: 10.1093/acprof:oso/9780195300314.003.0006

------. "Precursors and Mediators of Intergroup Reconciliation in Northern Ireland: A New Model." British Journal of Social Psychology 47 (2008), 481-495. Doi: 10.1348/014466607x238751

Noor, Masi, Nurit Shnabel, Samer Halabi, and Arie Nadler. "When Suffering Begets Suffering: The Psychology of Competitive Victimhood Between Adversarial Groups in Violent Conflict." Personality and Social Psychology Review 16, no. 4 (2012), 351-374. Doi: 10.1177/1088868312440048

Nordlinger, Eric. Conflict Regulation in Divided Societies. Cambridge, MA: Center for International Affairs, Harvard University, 1972.

Paluck, Elizabeth L. and Donald P. Green. "Prejudice Reduction: What Works? A Review and 
Assessment of Research and Practice." Annual Review of Psychology 60 (2009), 339-367. Doi: 10.1146/annurev.psych.60.110707.163607

Pilecki, Andrew and Phillip P. Hammack. “'Victims' Versus 'Righteous Victims': The Rhetorical Construction of Social Categories in Historical Dialogue Among Israeli and Palestinian Youth." Political Psychology 35, no. 6 (2014), 813-830. Doi: 10.1111/pops.12063

Ricigliano, Robert. Making Peace Last: A Toolbox for Sustainable Peacebuilding. New York: Routledge, 2012. Doi: $10.4324 / 9781315633565$

Scacco, Alexandra and Shana S. Warren. "Can Social Contact Reduce Prejudice and Discrimination? Evidence from a Field Experiment in Nigeria." American Political Science Review 112, no. 3 (August 2018), 654-677. Doi: 10.1017/s0003055418000151

Schechner, Richard. Performance Studies: An Introduction. New York: Routledge, 2013.

Schneider, Rebecca. Performing Remains: Art and War in Times of Theatrical Reenactment. New York: Routledge, 2011. Doi: 10.4324/9780203852873

Sherif, Muzafer. Experimental Study of Positive and Negative Intergroup Attitudes Between Experimentally Produced Groups: Robbers Cave Study. Tulsa: University of Oklahoma, 1954.

-------. "Superordinate Goals in the Reduction of Intergroup Conflict." American Journal of Sociology 63, no. 4 (1958), 349-356. Doi: 10.1086/222258

Taylor, Diana. The Archive and the Repertoire: Performing Cultural Memory in the Americas. Durham: Duke University Press, 2003.

United Nations. "Framework of Analysis for Atrocity Crimes: A Tool for Prevention." UN Office of the Special Advisers on Genocide Prevention and the Responsibility to Protect, 2014.

United States Holocaust Memorial Museum. "Early Warning Project - United States Holocaust Memorial Museum." Accessed June 21, 2017. https://www.ushmm.org/confront-genocide/ how-to-prevent-genocide/early-warning-project.

Verdeja, Ernesto. Unchopping a Tree: Reconciliation in the Aftermath of Political Violence. Philadelphia: Temple University Press, 2009.

Volkan, Vamik. Bloodlines: From Ethnic Pride to Ethnic Terrorism. New York: Farrar, Straus, and Giroux, 1997.

Walker, Donald, and Richard L. Gorsuch. "Dimensions Underlying Sixteen Models of Forgiveness and Reconciliation." Journal of Psychology and Theology 32, no. 1 (2004), 12-25. Doi: $\underline{10.1177 / 009164710403200102}$

Wallace, Marshall. "Tuzla, Bosnia: Cross-Ethnic Solidarity in the Face of Ethnic Cleansing." Case Study. Cambridge, MA: CDA Collaborative Learning Projects, 2002.

Waller, James. Confronting Evil: Engaging Our Responsibility to Prevent Genocide. New York: Oxford University Press, 2016.

Whigham, Kerry. "Performing Prevention: Civil Society, Performance Studies, and the Role of Public Activism in Genocide Prevention." In Reconstructing Atrocity Prevention, edited by Sheri P. Rosenberg, Tibi Galis, and Alex Zucker, 321-351. New York: Cambridge University Press, 2015. Doi: 10.1017/cbo9781316154632.016

---------. "Remembering to Prevent: The Preventive Capacity of Public Memory." Genocide Studies and Prevention 11, no. 2 (2017), 53-71. Doi: 10.5038/1911-9933.11.2.1447

Xiang, Peng, Haibo Zhang, Liuna Geng, Kexin Zhou, and Yuping Wu. "Individualist-Collectivist Differences in Climate Change Inaction: The Role of Perceived Intractability." Frontiers in Psychology 10 (2019). Doi: 10.3389/fpsyg.2019.00187 